\title{
ON MAGNETITE-BEARING PEGMATITES IN SE SOTTUNGA, ÅLAND ISLANDS
}

\author{
LENNART LAURÉN \\ Institute of Geology and Mineralogy, Åbo Akademi, Åbo 2, Finland
}

\begin{abstract}
Magnetite-bearing pegmatites of SE Sottunga, Aland Islands, are described. The pegmatites, which are probably granitization products, have derived their magnetite material from the iron-silicates of the host rocks, especially from the biotite. The field-observations and to some degree the distribution of the trace elements in the magnetite contradict a genetic connection with the small magnetite ores of the area.
\end{abstract}

\section{CONTENTS}

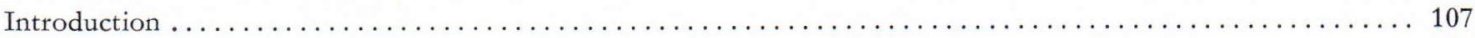

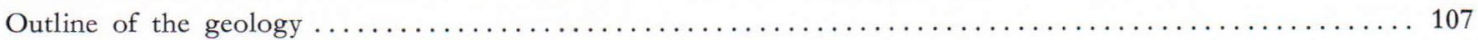

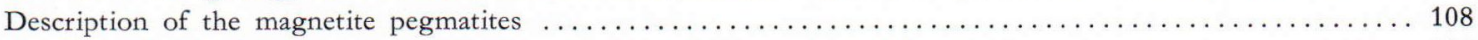

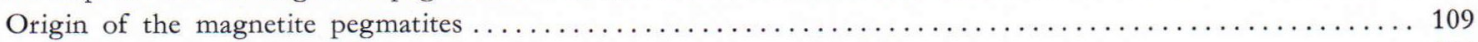

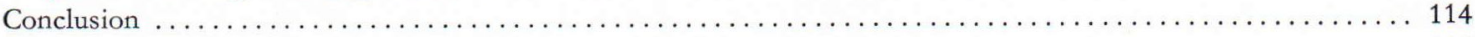

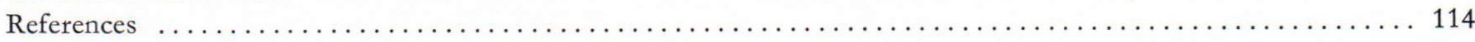

\section{Introduction}

The occurrence of magnetite-bearing pegmatites is a characteristic feature of the geology of SE Sottunga. Pegmatites of this type are common throughout the archipelago of SW Finland. They are also mentioned by Edelman (1956) in his description to the geological map, sheet No. 1033, Nötö. Saksela (1938)'discusses their importance in the genesis of the Jussarö iron ore. Magnetite-bearing pegmatites certainly occur also in other parts of Finland, but they have obviously not attracted the interest of the geologists, at least very little has been published about them.

The observations of this paper were made on the islands of Södö and Sälsö and their surroundings. (Fig. 1).

\section{Outline of the geology}

The dominating rock in the area is a gneissose granite in various stages of granitization, from a grey ungranitized variety to a pink variety re- 


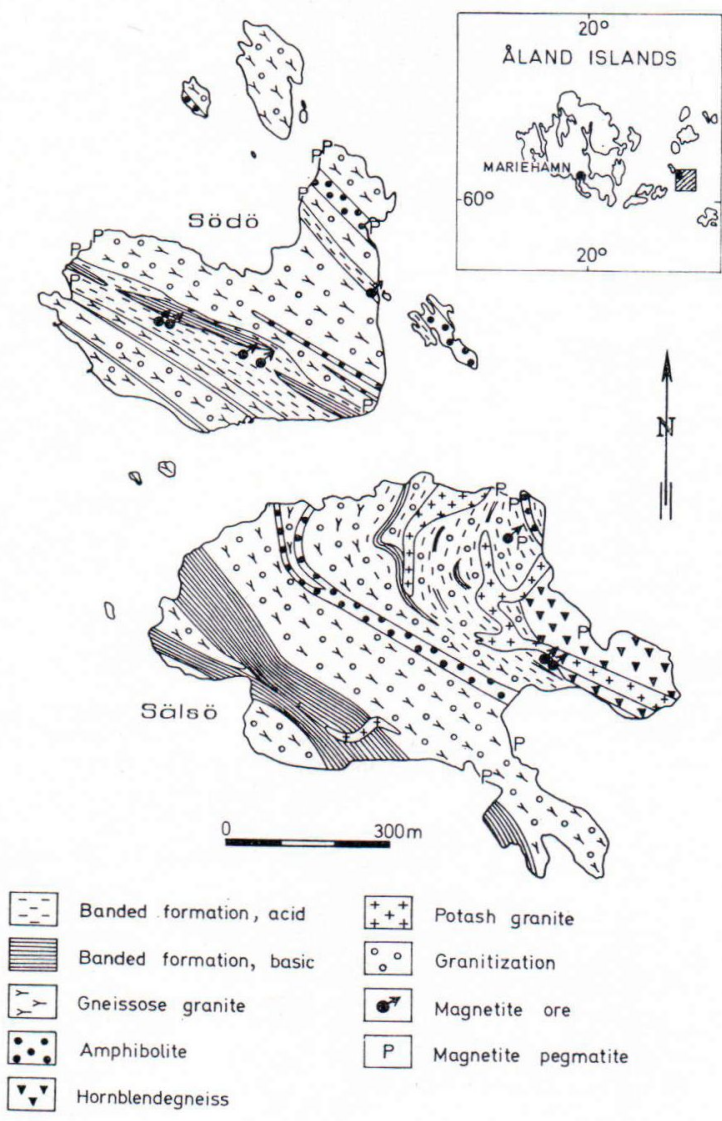

Fig. 1. Geological map of Södö and Sälsö.

sembling microclinegranite. The so-called banded formation (Edelman, 1960), a series of alternating leptitic and amphibolitic bands, strikes conformly with the gneissose granite. The leptite has been partly transformed into a coarser leptite gneiss. The leptitic part of the banded formation contains thin horizons and lenses of skarn. Some of these skarn bodies are very magnetite-rich, in fact they constitute small magnetite ores. The field relations of the gneissose granite and the banded formation strongly indicate a common sedimentary origin for these rocks. (Laurén, 1968).

A somewhat younger group of rocks consists of amphibolites and hornblendegneisses, originally basic intrusives.
The youngest rock in the area is a fine-grained, intrusive potash granite.

The magnetite-bearing pegmatites do not seem to follow any particular rock, they occur in all of them except the potash granite, which is hardly affected by the granitization at all.

\section{Description of the magnetite pegmatites}

The pegmatites vary from thin veins (Plate I, Fig. 3) to dikes with a width of over $10 \mathrm{~m}$ (Fig. 2). They have no preferred directions and in relation to the host rock there are both cutting and concordant types. The contact is generally sharp but especially in granitized gneissose granite there are gradual and diffuse contacts. The colour is mostly reddish but also pale varieties have been found. Some magnetite pegmatites have formed in zones of movement. (Plate I, Fig. 5). In the amphibolite of northern Södö an extremely magnetite-rich pegmatite was found. The mineral grains of this $0.5 \mathrm{~m}$ wide pegmatite were distinctly deformed (flattened).

The main minerals are plagioclase, $\mathrm{K}$-feldspar and quartz. Biotite, muscovite, chlorite, epidote, and sphene are the minor constituents. The significant mineralogical feature is the occurrence

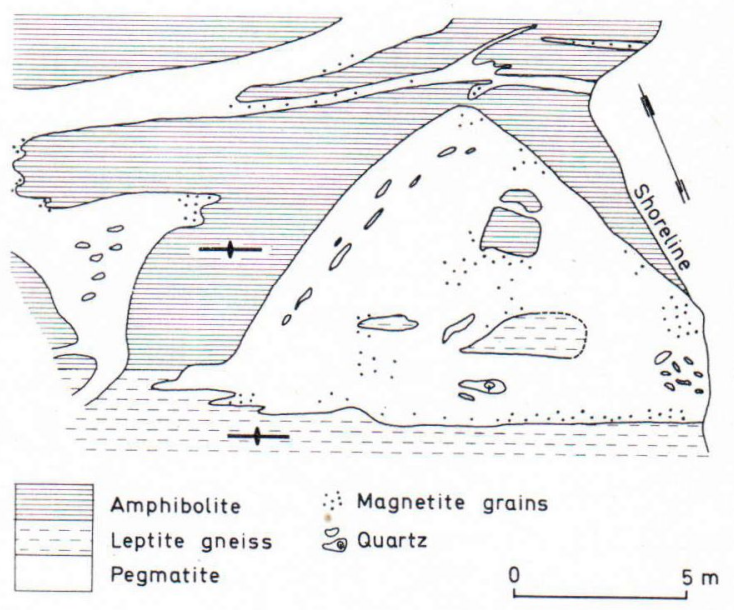

Fig. 2. Magnetite-bearing pegmatite. Sketch from the SEshore of Södö. 
of magnetite clots. Hornblende clots occur in some of the pegmatites. In a couple of pegmatites, crystals of a dark, weakly radioactive mineral were found, which by powder analysis were identified as sphene.

The magnetite occurs in the pegmatites as lumps or grains with a diameter from $0.5 \mathrm{~cm}$ to $3 \mathrm{~cm}$ (Plate I Figs. 1 and 2). In a few pegmatites some of the lumps consist of hematite. The lumps are anhedral and often somewhat elongated. The magnetite clots are generally not evenly distributed in the pegmatite but show a tendency to concentrate along the contacts and around the inclusions of the host rock. (Fig. 2 and Plate I, Fig. 1). The elongated grains are often parallel to each other, the direction (N80W - E-W) is quite uniform and does not coincide with the general foliation of the area (N70W). Sometimes the magnetite grains are orientated along the axial plane (Fig. 5).

\section{Origin of the magnetite pegmatites}

The first question that arises when attempting to explain the origin of the magnetite pegmatites is their relationship to the small magnetite ores in the area. According to Saksela (1938), the Jussarö ore in the archipelago south of the town Ekenäs (Tammisaari) is genetically connected with the magnetite-bearing pegmatites in that area. In this area there are in fact very few magnetite pegmatites in the close vicinity of the magnetite ores. There are a lot of pegmatites crossing the ore zone in Södö, but most of them are magnetite-free.

In order to compare the pegmatitic magnetite with the ore-magnetite a number of trace element determinations were made. The separation of the magnetite from the pegmatite was done with a hand magnet, Frantz' isodynamic separator and heavy liquids. The results are given in Table 1 and Fig. 3.

TABLe 1

The distribution of trace elements in magnetite from the ores, pegmatites and rocks in the Södö-Sälsö area. An analysis published by Marmo (1959) is included. All values in percent.

\begin{tabular}{|c|c|c|c|c|c|c|c|c|c|c|c|}
\hline & 1. & 2. & 3. & 4. & 5. & 6. & 7. & 8. & 9. & 10. & 11. \\
\hline $\mathrm{Ti}$ & 0.03 & 0.02 & 0.10 & 0.15 & 0.18 & 0.17 & 0.22 & 0.24 & 0.29 & 0.16 & 0.12 \\
\hline V & 0.001 & 0.002 & 0.016 & 0.009 & 0.003 & 0.004 & 0.120 & 0.037 & 0.012 & 0.028 & - \\
\hline $\mathrm{Cr}$ & $<0.001$ & $<0.001$ & $<0.001$ & $<0.001$ & $<0.001$ & $<0.001$ & 0.002 & $<0.001$ & 0.001 & $<0.001$ & - \\
\hline $\mathrm{Mn}$ & 0.23 & 0.28 & 0.22 & 0.34 & 0.16 & 0.05 & 0.23 & 0.28 & 0.17 & 0.22 & 0.16 \\
\hline Co & 0.018 & 0.010 & 0.002 & 0.005 & 0.001 & $<0.001$ & 0.003 & 0.003 & 0.002 & 0.003 & - \\
\hline $\mathrm{Ni}$ & 0.003 & 0.003 & $<0.001$ & $<0.001$ & $<0.001$ & $<0.001$ & 0.001 & $<0.001$ & 0.001 & 0.001 & - \\
\hline $\mathrm{Cu}$ & 0.025 & $0 \quad 017$ & 0.002 & $<0.001$ & $<0.001$ & $<0.001$ & 0.002 & $<0.001$ & 0.002 & $<0.001$ & - \\
\hline $\mathrm{Mg}$ & 0.10 & 0.14 & 0.04 & 0.36 & 0.09 & 0.03 & 0.06 & 0.04 & 0.04 & 0.06 & \\
\hline
\end{tabular}

1. Ore. Western pit, W-wall. Södö.

2. Ore. Western pit, N-wall. Södö.

3. Ore. Sample from waste dump, middle pit. Södö.

4. Ore. Northern shore of Sälsö.

5. Pegmatite. Södö, SE-shore.

6. Pegmatite. Södö, SE-shore.

7. Pegmatite. Sälsö, SE-cape.

If the ores and the pegmatites were formed at the same time from the same emanations, it is reasonable to assume that the two magnetites have a similar distribution of trace elements. On
8. Pegmatite. Sample from waste dump, eastern pit. Södö.

9. Magnetite-rich leptite gneiss. Österskär (skerry E of Södö). See also Fig. 7.

10. Magnetite-rich amphibolite (banded formation). Södö.

11. Magnetite pegmatite. Bumbuna, Sierra Leone. (Marmo, 1959).

the other hand, if the magnetite pegmatites formed after the ores but derived their magnetite material from the ores, the trace element distribution will in some degree depend on the 

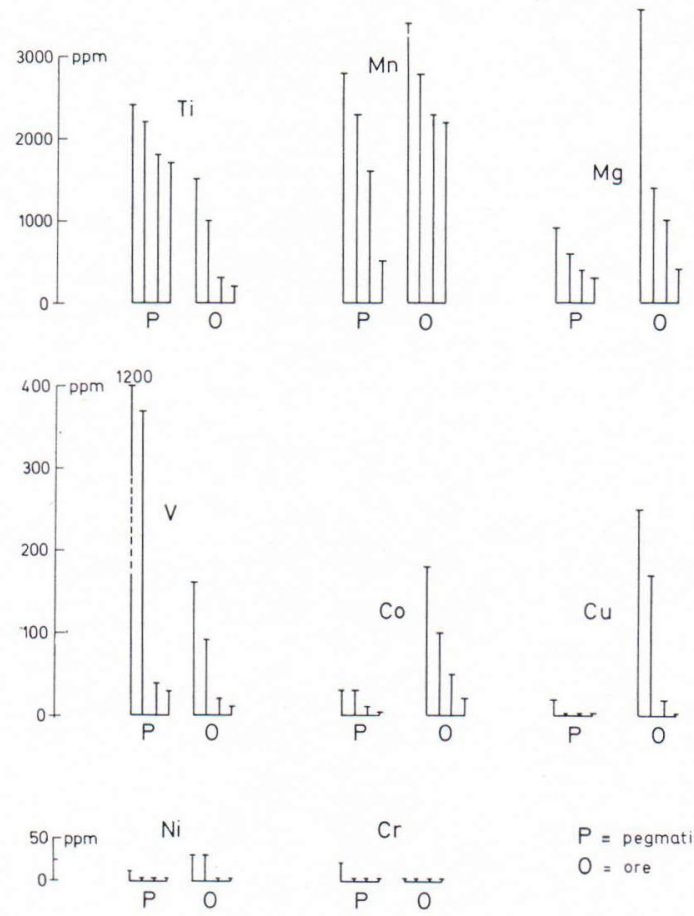

Fig. 3. Comparison between the trace element contents of the magnetite in the ores and the pegmatites of the Södö-Sälsö area.

distribution in the ores, but chiefly it will depend on the $\mathrm{P}, \mathrm{T}$-conditions under which the pegmatites formed (De Vore, 1955). Fig. 3 shows that there are neither great differences nor general similarities in the distribution of the trace elements. Most trace elements show a certain overlapping. Yet the Ti-content is higher in the pegmatite-magnetite whereas the $\mathrm{Co}$ - and $\mathrm{Cu}$ contents seem to be higher in the ore material.

The distribution of the trace elements does not point to a common origin of ores and pegmatites, a fact that is further confirmed by the field observations.

Very characteristic of the magnetite pegmatites is the fact that the magnetite grains are concentrated close to the contacts and inclusions of the host rock (Plate I, Fig. 1). This indicates some relationship between the formation of the magne- tite and the host rock. If the magnetite had derived its constituents from the ores, it would have been a mere recrystallization of the magnetite. If one assumes that the necessary iron originates from the host rocks, the situation alters. Only the amphibolites may have enough magnetite for the segregation and recrystallization of such lumps. For the most part the only Fe-sources, which can be considered, are the Fe-silicates i.e. biotite and hornblende. The iron of the biotite and hornblende is generally ferro-iron, which means that a transformation of biotite or hornblende to magnetite is also an oxidation reaction.

Eugster and Wones (1962) have experimentally investigated the stability relations of annite i.e. the pure Fe-biotite. Under varying temperature and oxygene fugacity they obtained four different decomposition-reactions, one of them yielding K-feldspar + magnetite (Fig. 4).

The results show that at a confining pressure of 2070 bars, annite can transform into sanidin + magnetite at temperatures between $425^{\circ}$ and $825^{\circ} \mathrm{C}$. If quartz is present, the same reaction

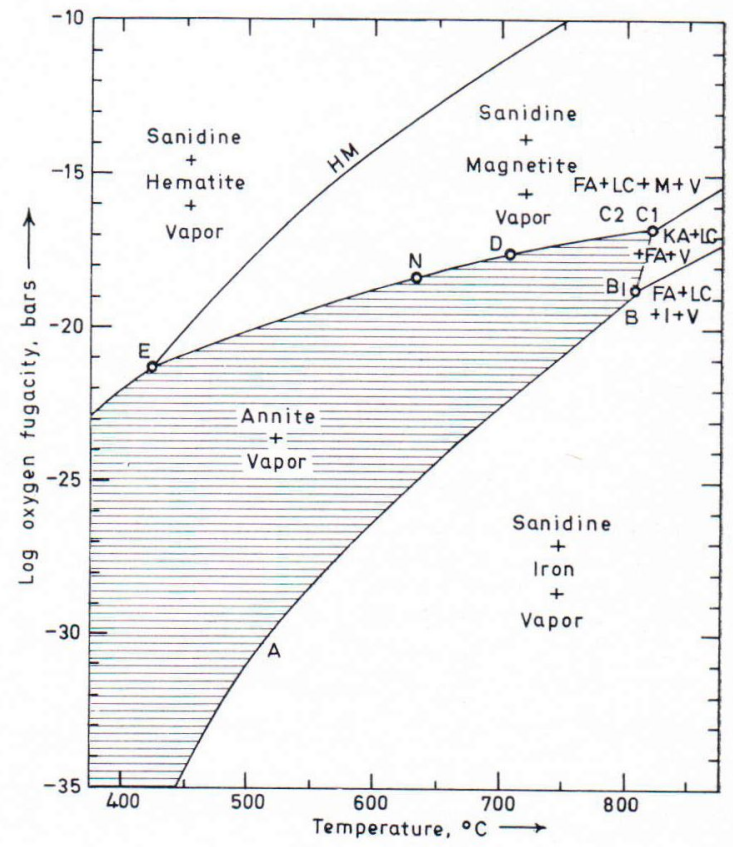

Fig. 4. The stability relations of annite according to Eugster and Wones (1962). 
occurs between $425^{\circ}$ and $705^{\circ} \mathrm{C}$. If the pressure is lowered, the stability field of annite is decreased. By constant oxygen fugacity, hematite is always formed at a lower temperature than magnetite.

Winkler (1965) has made anatectic experiments with paragneisses of various composition. The results show that biotite can undergo different reactions. By oxidating conditions the following reaction occurs:

Biotite $+\mathrm{O}_{2} \rightarrow$ ortoclase $+\mathrm{Ti}$ - and Albearing magnesioferrit $\left(\mathrm{MgFe}_{2} \mathrm{O}_{4}\right)$

Winkler's comments to this reaction are that oxidating conditions can hardly be expected in natural anatexis.

To what degree these experiments can be applied to real geological conditions is difficult to decide. The forementioned experiments of Eugster and Wones dealt with annite, whereas natural biotite always has a Mg-component. Later investigations (Wones and Eugster, 1965) show that biotite can even have similar equilibrium relations with magnetite.

Microscopic investigations give some slight evidence of the transformation of biotite into magnetite. The magnetite grains have small inclusions of biotite. A thin section from a contact between pegmatite and a leptite inclusion shows that the biotite of the leptite has abundant inclusions of magnetite. Magnetite inclusions in biotite are a common phenomenon, but in this case the number of inclusions clearly increases on approaching the contact. Some magnetite grains in the leptite look like pseudomorphs after biotite.

One would assume that the $\mathrm{Mg}$-component of the biotite would form some mineral of its own, for instance cordierite, but no such $\mathrm{Mg}$ minerals have been found in the pegmatites. The chemical analyses of the large pegmatite on the SE-shore of Södö also show a uniformly low Mg-content:

$\begin{array}{lccl} & \mathrm{FeO} & \mathrm{Fe}_{2} \mathrm{O}_{3} & \mathrm{MgO} \\ \text { Magnetite-bearing part } & 0.7 & 1.0 & 0.1 \\ \text { Magnetie-free part } & 0.4 & 0.1 & 0.09\end{array}$

As it is highly improbable that the biotite is very $\mathrm{Mg}$-poor, the evident explanation is that the Mg-component has been transported elsewhere.

In this area the most obvious process to cause such a removal of $\mathrm{Mg}$ is granitization. The gneissose granites of the area in particular are intensely granitized. Chemical analyses of the gneissose granites also show a typical decrease of $\mathrm{Ca}, \mathrm{Mg}$ and $\mathrm{Fe}$ and an increase of $\mathrm{K}$ when gneissose granite (trondhjemite) via porphyroblastic granite is granitized to red gneissose granite (microcline granite) (Table 2). This explanation implies that the pegmatites themselves are granitization products.

\section{TABLE 2 .}

Chemical composition of various types of gneissose granite. Analyses performed by Pargas Kalkbergs Ab

\begin{tabular}{|c|c|c|c|}
\hline & 1. & 2. & 3. \\
\hline $\mathrm{SiO}_{2} \ldots \ldots \ldots \ldots \ldots \ldots$ & 73.4 & 73.4 & 76.9 \\
\hline $\mathrm{TiO}_{2} \quad \ldots \ldots \ldots \ldots \ldots$ & 0.37 & 0.03 & 0.01 \\
\hline $\mathrm{Al}_{2} \mathrm{O}_{3} \ldots \ldots \ldots \ldots$ & 13.7 & 12.8 & 11.7 \\
\hline $\mathrm{Fe}_{2} \mathrm{O}_{3} \ldots \ldots \ldots \ldots \ldots$ & 0.4 & 0.1 & 0.1 \\
\hline $\mathrm{FeO} \ldots \ldots \ldots \ldots \ldots \ldots$ & 1.8 & 1.8 & 0.7 \\
\hline $\mathrm{MnO} \ldots \ldots \ldots \ldots \ldots \ldots$ & 0.05 & 0.02 & 0.01 \\
\hline $\mathrm{MgO} \ldots \ldots \ldots \ldots \ldots \ldots$ & 0.5 & 0.4 & 0.1 \\
\hline $\mathrm{CaO} \ldots \ldots \ldots \ldots \ldots$ & 2.8 & 2.5 & 0.2 \\
\hline $\mathrm{Na}_{2} \mathrm{O} \ldots \ldots \ldots \ldots \ldots$ & 4.8 & 3.0 & 3.5 \\
\hline $\mathrm{K}_{2} \mathrm{O} \ldots \ldots \ldots \ldots \ldots \ldots \ldots \ldots \ldots$ & 0.9 & 3.9 & 4.7 \\
\hline $\mathrm{P}_{2} \mathrm{O}_{5} \quad \ldots \ldots \ldots \ldots \ldots \ldots$ & 0.1 & 0.07 & 0.01 \\
\hline $\mathrm{H}_{2} \mathrm{O}+\ldots \ldots \ldots \ldots \ldots$ & 0.6 & 1.0 & 0.3 \\
\hline \multirow{2}{*}{$\mathrm{H}_{2} \mathrm{O}-\ldots \ldots \ldots \ldots \ldots$} & 0.16 & 0.09 & 0.06 \\
\hline & 99.6 & 99.2 & 98.3 \\
\hline
\end{tabular}

1. Grey genissose granite (trondhjemite). Södö.

2. Porphyroblastic gneissose granite. Sälsö.

3. Red gneissose granite (microcline granite). Södö.

Considering the relationship of the pegmatites to the host rock one sees that the contacts are of varying nature. There are sharp and cutting, sharp and concordant as well as gradual contacts. One cannot find any contact-influence on the host rock. On the other hand, in some places one can recognize old directions in the pegmatites. 


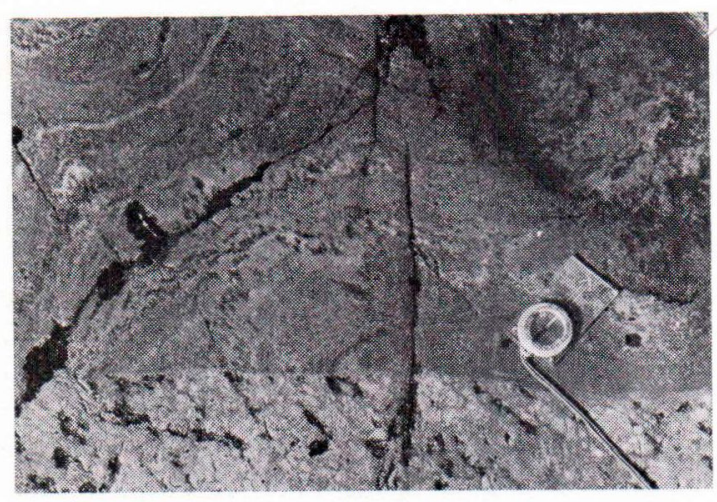

Fig. 5. Contact between magnetite pegmatite (bottom) and leptite gneiss. The magnetite grains are orientated along the axial plane. Sälsö, N-shore.

In Fig. 5 a magnetite pegmatite sharply cuts a leptite gneiss. The gneiss has a well developed axial foliation. The striking feature is that the magnetite grains of the pegmatite are orientated in the same direction. It is very improbable that the folding (and the development of the axial foliation) occurred after the formation of the pegmatite. A more plausible explanation is that the magnetite grains have grown along an axial plane direction which existed before the pegmatite. Another possibility is that the leptite gneiss was folded first. Then the pegmatite began to form, but the deformation continued with the same stress directions, causing an orientation of the magnetite grains. This explanation presumes a very constant direction of the stressfield during a considerable elapse of time, which to the author seems rather unlikely.

Axial plane orientation of the magnetite grains in the pegmatites with diffuse and gradual contacts can also be observed in the area.

If the orientation of the magnetite in the axial plane means a preserved, former direction, it eliminates an intrusive character of these pegmatites. They must have formed in a »calmer» way, i.e. metasomatically. Partial anatectic melting could also be possible, particularly in the case of Fig. 5, where the sharp contact conflicts somewhat with a purely metasomatic origin. As there are also other field observations indicating the non-intrusive character of the pegmatites of the area, it is reasonable to consider them as products of granitization.

The next question is how Eugster's and Wones' experimental data on the transformation of annite into magnetite and $\mathrm{K}$-feldspar correspond to the $\mathrm{P}, \mathrm{T}$-conditions of the granitization. Ramberg (1952) gives some approximative P, T-limits for the granitization:

$$
\begin{aligned}
& \mathrm{P}=\text { some hundreds }-5000-10000 \mathrm{~atm} \\
& \mathrm{~T}=300^{\circ}-700^{\circ} \mathrm{C}
\end{aligned}
$$

Eugster's and Wones' data on the annitemagnetite-reaction are:

$$
\begin{aligned}
& \mathrm{P}=2070 \text { bars } \\
& \mathrm{T}=425^{\circ}-705^{\circ} \mathrm{C}
\end{aligned}
$$

According to these figures, magnetite can form from annite (biotite) under granitization conditions.

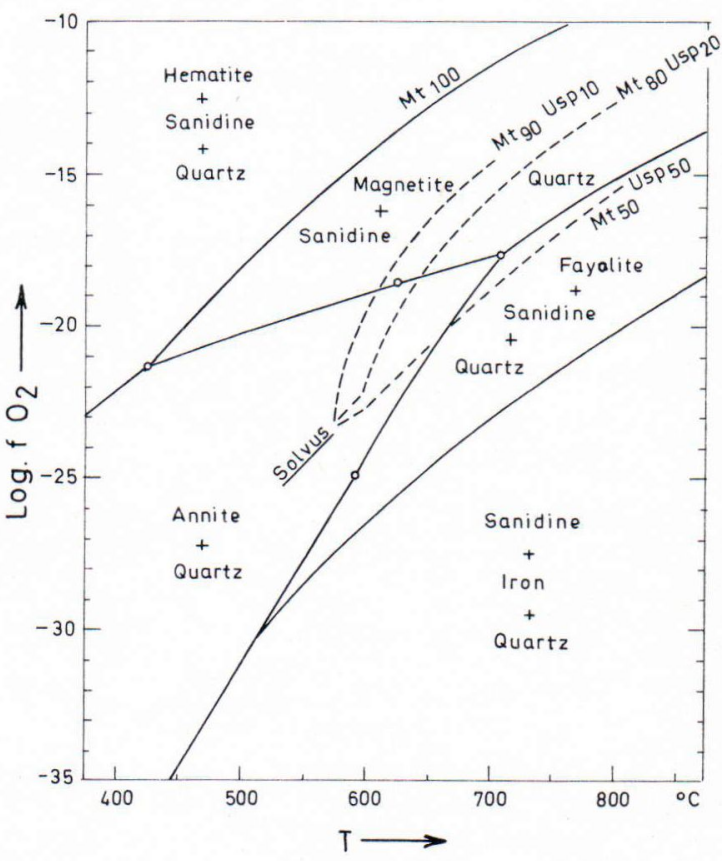

Fig. 6. Combination of the stability relations of annite (Eugster) and the data on magnetite-ulvöspinell (Buddington). 
The Ti-content of the magnetite can also give some information concerning the conditions of formation. Buddington and Lindsley (1964) have investigated solid solutions of the Fe-Ti-oxides and their dependence on temperature and oxygen fugacity. In their opinion, magnetite can contain Ti principally as a solid solution of ulvöspinell $\left(\mathrm{Fe}_{2} \mathrm{TiO}_{4}\right)$. Accordingly the common intergrowths of magnetite and ilmenite $\left(\mathrm{FeTiO}_{3}\right)$ are the result of an oxidation of this solid solution. The experimental results presume the co-existence of the pair hematite-ilmenite.

The $\mathrm{TiO}_{2}$-content of the pegmatitic magnetite is quite low $(0.3-0.4 \%)$. In the magnetiteulvöspinell-series it is roughly equivalent to the composition $\mathrm{Mt}_{\mathbf{9} 9} \mathrm{Usp}_{\mathbf{1}}$. Buddington's and Lindsley's results show that magnetite and ulvöspinell are not mixable anymore under $550^{\circ} \mathrm{C}$. If the oxygen fugacity increases at a constant temperature, the $\mathrm{TiO}_{2}$-content will decrease. Applied to the magnetite of the pegmatites this indicates a high oxygen fugacity at the formation of the magnetite. Also Buddington, Fahey and Vlasidis (1955) point out the low $\mathrm{TiO}_{2}$-content $(0.51 \%)$ of the magnetite of a metamorphic microcline pegmatite from the Adirondacks area.

The question can be posed as to why the formation of the pegmatites is favourable to the transformation of biotite into magnetite. According to Eugster and Wones the following changes of the conditions promote the reaction:

1. Decrease of $T$ at constant $f_{02}$ and $P$

2. Decrease of $P_{v a p}$ at constant $f_{02}$ and $T$

3. Increase of $f_{02}$ at constant $T$ and $P_{v a p}$

It is generally assumed that the formation of pegmatites is favoured by zones of fracturing, movement or other weakness. In a zone of fracturing there should be more possibilities for a decrease of $\mathrm{P}_{\mathrm{vap}}$ or $\mathrm{T}$ than in the surrounding rock. As the annite-magnetite-transformation is a redoxreaction, the oxygen fugacity is probably the most important factor. The oxygen fugacity is very dependent on the presence of water in the system. Water which is in contact with the

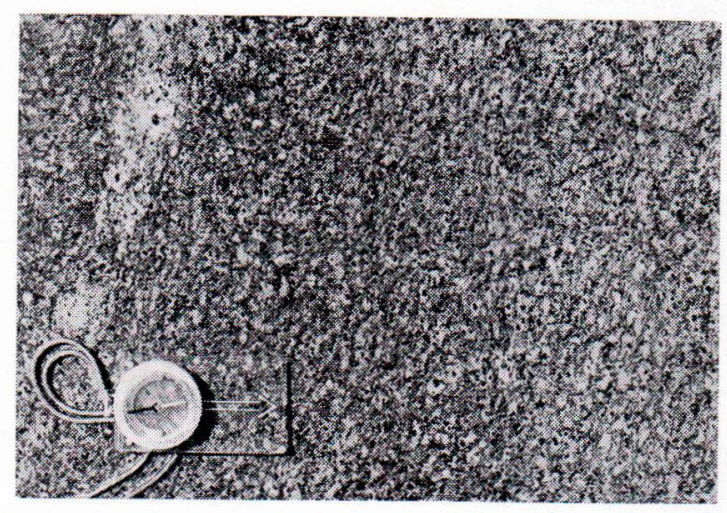

Fig. 7. Magnetite impregnation (black dots) in leptite gneiss. Skerry W of Södö.

atmosphere can contain dissolved oxygen. At greater depths it can produce oxygen by thermal dissociation. A zone of weakness is generally more permeable to water than the surroundings, which entails possibilities for a higher oxygen fugacity.

This does not mean that the biotite-magnetitetransformation is necessarily bound to the formation of pegmatites. In some places in this area a magnetite impregnation in the leptite gneiss occurs (Fig. 7).

It is improbable that all this magnetite originates from biotite, but one can discern a certain differentiation. The magnetite grains are surrounded by a distinct bleached zone. There are small venitic pegmatite veins in the rock, which always have larger magnetite grains (Plate I, Fig. 6). It is possible that the magnetite grains have formed in this case by the combined action of the segregation of the existing magnetite and the transformation of the biotite. Similar bleached rings around garnet porphyroblasts in kinzigite gneiss from Pargas have been described by Metzger (1945), who considers them to be the result of metamorphic differentiation. Hewitt (1960) describes a case of metamorphic reconstitution occurring in the nepheline syenite of Blue Mountain, Ontario. The first step in the process in the segregation of the biotite into clots, the 
second and final the replacement of the biotite clots by magnetite.

In the foregoing only biotite has been treated as an Fe-source for the magnetite. This is partly because of the lack of experimental data concerning the stability of hornblende. On the other hand, in this area hornblende seems to behave in a slightly different way from biotite in granitization. There are many hornblende-bearing pegmatites, where the hornblende porphyroblasts show the same characteristic concentration along the contacts as the magnetite. These pegmatites occur chiefly in basic rocks. Magnetite pegmatites also occasionally contain hornblende. This indicates that hornblende segregates and recrystallizes rather than undergoes transformation by the formation of pegmatites.

\section{Conclusion}

The discussion of magnetite-bearing pegmatites of SE Sottunga and their origin can be concluded by the following points:
1. The pegmatites are, disregarding the magnetite, simple pegmatites and probably products of granitization.

2. The behaviour of the magnetite shows that its constituents originate from the host rock, but not from the magnetite ores.

3. The magnetite forms chiefly by the transformation of biotite; hornblende is probably of less importance as an Fe-source.

4. The reaction annite $\rightarrow$ magnetite, which is a redoxreaction, is promoted by conditions which could exist in the formation of the pegmatites.

5. Taking the risk of generalizing the magnetite pegmatites could be called a special case of granitization in an oxidating milieu.

Acknowledgements - The author is indebted to Professor Nils Edelman for critically reading the manuscript. I also wish to thank the Geological survey of Finland for the trace element determinations, Pargas Kalkbergs $\mathrm{Ab}$ for the chemical analyses, and Mrs. Inge Skou for drawing the pictures.

\section{REFERENCES}

Buddington, A. F., Joseph Fahey and Angelina Vlisidis (1955). Thermometric and petrogenetic significance of titaniferous magnetite. Amer. J. Sci., Vol. 253.

Buddington, A. F. and D. H. Lindsley (1964). Irontitanium oxide minerals and synthetic equivalents. J. Petr., Vol. 5.

DeVore, George W. (1955). The role of adsorption in the fractionation and distribution of elements. J. Geol., Vol. 63, No. 2.

Edelman, Nils (1956). Suomen geologinen kartta Geological Map of Finland - Lehti - Sheet - 1033, Nötö. Kallioperäkartan selitys - Explanation to the map.

Edelman, Nils (1960). The Gullkrona region, SW Finland. Bull. Comm. Géol. Finlande 187.

Eugster, Hans P. (1959). Reduction and oxidation in metamorphism, in P. H. Abelson, ed., Researches in Geochemistry. Wiley, New York.

Eugster, Hans P. and D. R. Wones (1962). Stability relations of the ferruginous biotite, Annite. J. Petr., Vol. 3.
Hewits, D. F. (1960). Nepheline syenite deposits of Southern Ontario. Ont. Dept. Mines, Vol. LXIX, Part 8.

LAurén, L. (1968). Södö-Sälsö-områdets geologi, dess malmer och magnetitförande pegmatiter. Treatise in the archives of the Institute of Geology and Mineralogy, Åbo Akademi.

MARMo, Vladi (1959). On the $\mathrm{TiO}_{2}$-content of magnetite as a petrogenetic hint. Amer. J. Sci., Vol. 257.

Metzger, Adolf A. T. (1945). Zur Geologie der Inseln Ålö und Kyrklandet. Acta Acad. Aboens. XV, 3.

RAMBerg, Hans (1952). The origin of metamorphic and metasomatic rocks. The University of Chicago Press.

SaKsela, MartTi (1938). Ueber einige Eiseneze in Jussaarigebiet SW Finnland. Bull. Comm. Géol. Finlande 125.

Winkler, Helmut G. F. (1965). Die Genese der metamorphen Gesteine. Springer, Berlin.

Wones, D. R. and H. P. Eugster (1965). Stability of biotite: Experiment, theory and application. Am. Mineral., Vol. 50.

Manuscript received, November 1, 1968. 
PLATE I

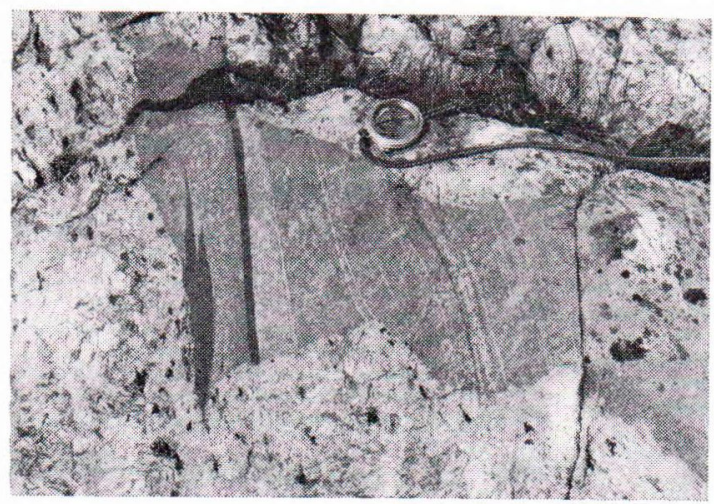

Fig. 1. Xenolith of acid banded formation in pegmatite, surrounded by magnetite grains. Varpskär, W of Södö.

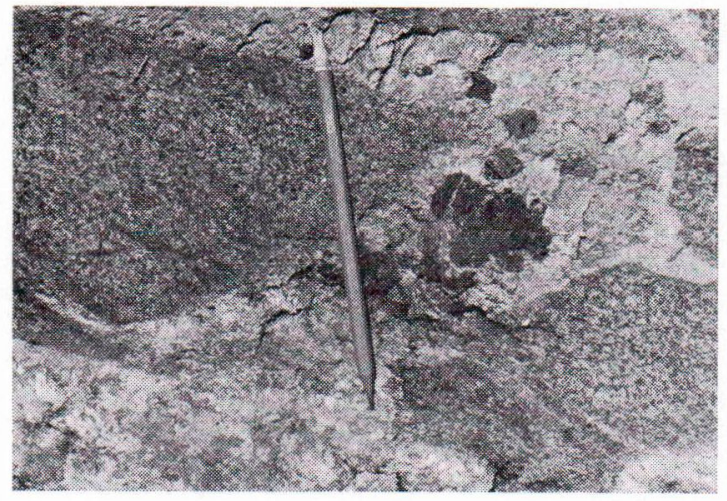

Fig. 3. Pegmatite vein in hornblendegneiss with grains of magnetite and hematite. Sälsö.

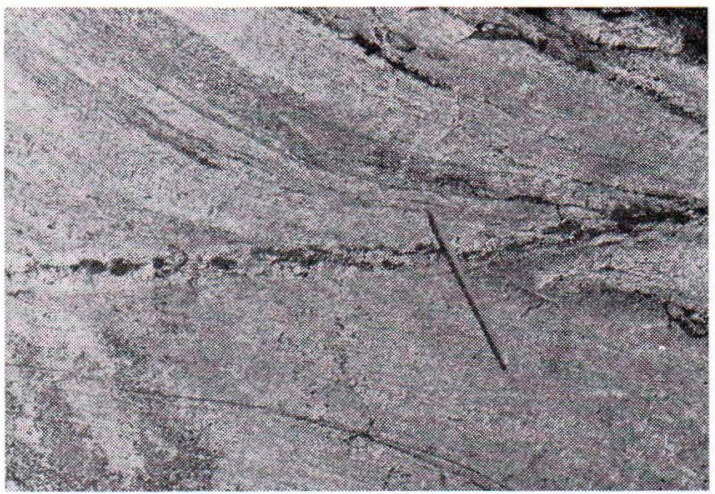

Fig. 5. Magnetite-bearing pegmatite vein, which has developed along a shear surface. Sälsö.

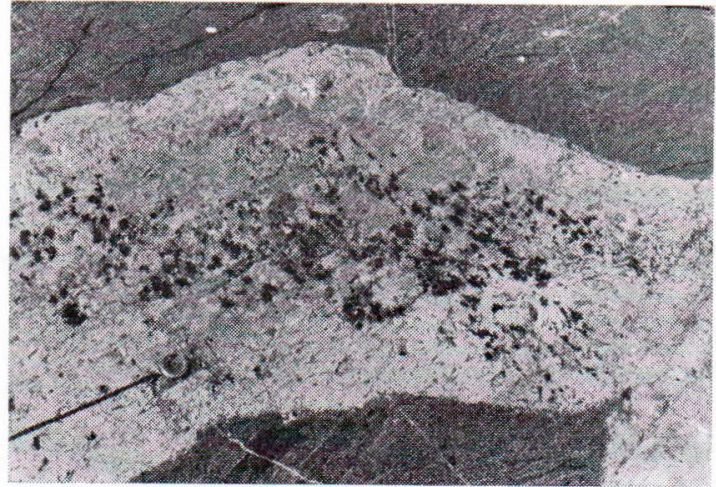

Fig. 2. Magnetite-rich pegmatite in gabbroid amphibolite. Jungklubb, S of Sälsö.

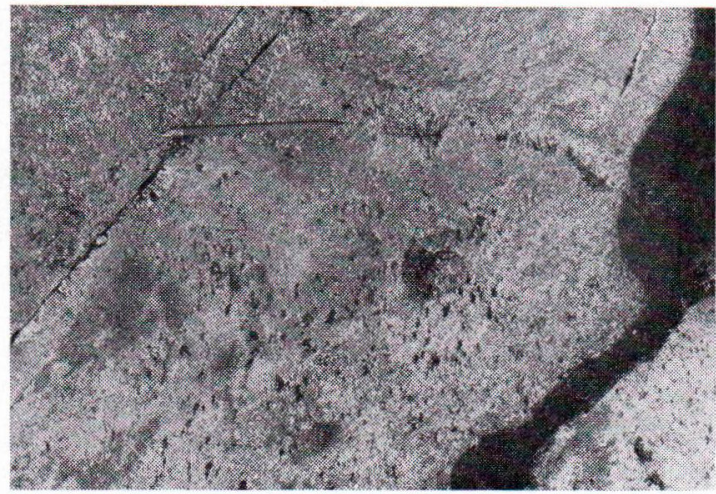

Fig. 4. Parallellorientated magnetite grains in pegmatite. The dark rim along the contact against leptite gneiss is biotite. Sälsö.

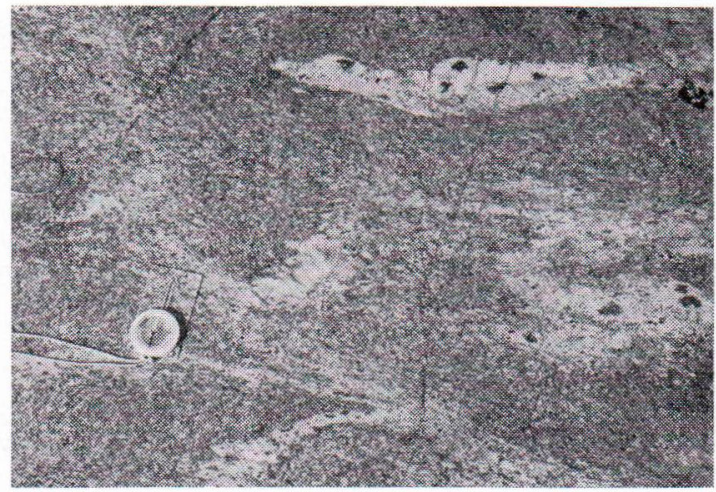

Fig. 6. Magnetite impregnated leptite gneiss. Note bigger magnetite grains in the pegmatitic veinlets. Skerry NW of Södö. 